\title{
Anticoagulation Treatment for Patients with Coronavirus disease 2019 (COVID-19) and its clinical effectiveness in 2020: A meta-analysis study
}

\author{
Jingyi Ge \\ Beijing Rehabilitation Hospital \\ Yingmin Ma ( $\nabla$ ma.yingmin@163.com) \\ Capital Medical University https://orcid.org/0000-0002-2311-9712 \\ Zhipeng Wu \\ Beijing Chaoyang Hospital \\ Jiawei Jin \\ Beijing Chaoyang Hospital \\ Xiao Sun \\ Tulane University School of Public Health and Tropical Medicine
}

\section{Research}

Keywords: Covid-19, Anticoagulation, Bleeding, Thrombosis

Posted Date: May 25th, 2021

DOI: https://doi.org/10.21203/rs.3.rs-551086/v1

License: (c) (7) This work is licensed under a Creative Commons Attribution 4.0 International License. Read Full License

Version of Record: A version of this preprint was published at Medicine on November 24th, 2021. See the published version at https://doi.org/10.1097/MD.0000000000027861. 


\section{Abstract \\ Objective}

To better inform efforts to treat and control the current outbreak with effective anticoagulant treatment strategies for coronavirus disease 2019 (Covid-19) patients.

\section{Methods}

We searched Cochrane Library, Pubmed, EMBASE, MEDLINE, SCIEXPANDED, Web of Science, Google Scholar, CNKI (Chinese Database), WanFang (Chinese Database), CBM (Chinese Database), VIP (Chinese Database) for studies published from November 1st 2019 to October 1, 2020, and we searched references of identified articles. Studies were reviewed for methodological quality. A random-effects model was used to pool results. Heterogeneity was assessed using $R$. Publication bias was assessed using funnel plot.

\section{Results}

Fourteen studies involving 7,681 patients were included. We meta-analyzed the bleeding, deep vein thrombosis and pulmonary embolism risk between no anticoagulation and prophylactic anticoagulation, and found no significant difference. The same trend occurred in the comparison between with and without anticoagulation. However, when compared with no anticoagulation, both prophylactic anticoagulation (OR $=0.80,95 \% \mathrm{Cl}$ : $0.69-0.93)$ and therapeutic anticoagulation $(\mathrm{OR}=0.91,95 \% \mathrm{Cl}: 0.80-1.05)$ had lower risk of mortality. Furthermore, the risk of overall bleeding among patients with therapeutic anticoagulation was 3.11 times (95\% Cl: $2.29-4.24)$ than that of patients with prophylactic anticoagulation, on the contrary, therapeutic anticoagulation had lower risk of deep vein thrombosis than prophylactic anticoagulation $(\mathrm{OR}=0.34,95 \% \mathrm{Cl}$ : $0.19-0.63)$.

\section{Conclusions}

Among Covid-19 patients, preventive and therapeutic anticoagulation were more beneficial than no anticoagulation for reducing mortality risk. The result will inform healthcare providers and public health policy makers in their efforts to treat and control the current outbreak.

\section{Introduction}

Severe acute respiratory syndrome coronavirus 2 (SARS-CoV-2) causes an ongoing global pandemic of coronavirus disease 2019 (Covid-19), leading to more than 135 million global infections and a mortality rate of $2.1 \%{ }^{1}$. Several recent studies have shown that patients with Covid-19 frequently have coagulation disorders ${ }^{2-6}$. These abnormal coagulation parameters have been associated with worse outcomes ${ }^{2,3}$. Deaths among people with Covid-19 have been partially attributed to venous thromboembolism and arterial thromboses ${ }^{7,8}$. In intensive care settings, prevalence of venous thromboembolism among patients with Covid-19 has been reported at about $30 \%{ }^{9}$. Several scientific societies and authors, including the American Society of Hematology, International Society on Thrombosis and Haemostasis ${ }^{10}$, CHEST Guideline and Expert Panel ${ }^{11}$, and others have already proposed specific guidelines and recommendations on the use of thromboprophylaxis in patients with Covid-19.

In multiple studies, venous thromboembolism (VTE), arterial thrombosis, and microvascular thrombosis have all been described ${ }^{12-15}$. And previous observational cohort studies have found evidence that use of anticoagulation in patients with Covid-19 was associated with decreased risk of mortality ${ }^{16,17}$; however, these studies were limited in sample size or used relatively small healthcare systems. High VTE rates have been reported in critically ill Covid-19 patients despite the use of prophylactic anticoagulation ${ }^{12,18}$. Higher level of evidence-based medicine was needed to determine whether anticoagulant therapy was necessary for Covid-19 patients.

Although our understanding of the hematologic manifestations of Covid-19 remains in its early stages, this systematic review aims to provide a summary of current estimates of VTE risk, and their association with poor outcomes, discuss benefits and harms of anticoagulation, and provide suggestions for the prevention and management of this infection in Covid-19 patients.

\section{Methods}

\section{Search Strategy and Study Selection}

Our systematic review and meta-analysis was undertaken according to Preferred Reporting Items for Systematic Reviews and Meta-Analyses (PRISMA) guidelines (Supplementary table 1) and the protocol has been registering in the PROSPERO database (Registration number: CDR42021233116).

A literature search was performance using the electronic database of Cochrane Central Database, PubMed, EMBASE, MEDLINE, SCIEXPANDED, Web of Science, Google Scholar, CNKI (Chinese Database), WanFang (Chinese Database), CBM (Chinese Database), VIP (Chinese Database) from November 1 st 2019 to October 1st, 2020, with the following search terms: ("coronavirus" or "nCoV" or "SARS-CoV-2" or "COVID-19") and ("anticoagulant" OR "anticoagulation" OR "heparin") We complemented the search by checking the grey literature and cross- referencing relevant reviews identified in current study.

\section{Inclusion and Exclusion Criteria}


Articles were included based on the following characteristics: the studies had observational studies or randomized controlled trials of confirmed Covid-19 subjects having data available on anticoagulation treatment and associated outcomes. The outcomes contains bleeding, thrombosis or mortality events. The articles were excluded if the 1) research articles that focused on patients with precondition that may lead to bleeding, previous use of anticoagulant therapy; 2 ) the articles with overlapping data; 3 ) the articles had insufficient data, such as the study enrolled less than 10 patients. The review articles, conference reports, case reports, letters to the editor, editorials and expert opinions were excluded as well.

\section{Data Abstraction and Quality Assessment}

Data were collected by 3 independent reviewers (Jingyi Ge, Xiao Sun and Yingmin Ma) and duplicate articles were deleted by Endnote X8 software. There reviewers independently screened the titles and abstracts of the retrieved articles to exclude obvious irrelevant studies. The full text of potentially relevant studies would then be reviewed in accordance with the prespecified criteria. If authors of the studies were similar or data were extracted from the same database, the study period would be noted. Only the latest study would be included if the study period overlaps. Any disagreement between authors will be resolved by consensus with a third author (Yingmin Ma). In the case of data missing, we would contact original trial authors requesting for clarifications and more data.

The risk of bias in enrolled studies will be independently assessed by all reviewers, any discrepancy will be resolved by discussion. Quality assessment of included articles was conducted by Newcastle-Ottawa Scale (NOS) ${ }^{19}$ which consisted of three parameters: selection, comparability, and exposure assessment (Supplementary table 2). The potential risk of bias in each clinical trial will be evaluated by Cochrane collaboration tool ${ }^{20}$ through seven domains (Supplementary table 3). Each of the domains will be scored as "low risk", "high risk" or "Unclear".

\section{Data Analyses}

Data synthesis and analysis was performed using STATA (version 15). Random-effects meta-analysis was used to calculate an overall proportion or a summary estimate of means of each outcome. They are pooled estimated ratios of component proportion of clinically apparent bleeding, thromboembolism (including deep venous thrombosis and pulmonary embolism) and in-hospital all-cause mortality with 95\% confidence intervals of different groups (undergoing anticoagulant therapy vs no anticoagulant therapy, therapeutic anticoagulant therapy vs preventive anticoagulant therapy) of Covid-19 patients. To minimize the impact of studies with extremely small or extremely large effectiveness estimates on overall estimates, Freeman-Tukey double arcsine transformation was used to stabilize the variance of specific prevalence rates before conducting random-effects meta-analysis models.

Heterogeneity between studies was assessed using $R$, with threshold values of $25 \%, 50 \%$, and $75 \%$ representing low, moderate, and high heterogeneity, respectively. If substantial heterogeneity $(R>75 \%)$ was detected, we further explored the possible source of heterogeneity through subgroup analysis. Publication bias was assessed by funnel plot ${ }^{21}$.

\section{Result}

Our initial search yielded 1,024 records and reduced to 683 after removing duplicates. We then excluded the records with only the title and abstract, leaving 109 remaining. The records were further excluded the studies with less than 10 cases, no research-related intervention measures, and no research-related outcome events. Ultimately, 14 records were used in the final quantitative synthesis. (Fig. 1).

\section{Study Characteristics}

Table 1 summarizes characteristics of included studies ${ }^{16,22-34}$. 
Table 1

Characteristics of studies reporting Coronavirus disease 2019 associated coagulation disorder and clinical outcomes

\begin{tabular}{|c|c|c|c|c|c|c|c|c|c|c|c|c|}
\hline \multirow[t]{2}{*}{ Author } & \multirow[t]{2}{*}{ Ref } & \multirow[t]{2}{*}{ Year } & \multirow[t]{2}{*}{ Country } & \multirow[t]{2}{*}{ Study design } & \multirow{2}{*}{$\begin{array}{l}\text { Study } \\
\text { period }\end{array}$} & \multirow{2}{*}{$\begin{array}{l}\text { Sample } \\
\text { size }\end{array}$} & \multirow{2}{*}{$\begin{array}{l}\text { Age (year, } \\
\text { mean } \pm \text { sd/ } \\
\text { Median[IQR]) }\end{array}$} & \multirow{2}{*}{$\begin{array}{l}\text { Sex } \\
\text { (male } \\
\%)\end{array}$} & \multirow{2}{*}{$\begin{array}{l}\text { BMI (kg/m2, } \\
\text { mean } \pm \text { sd/ } \\
\text { Median[IQR]) }\end{array}$} & \multicolumn{3}{|c|}{ Number of Outcomes } \\
\hline & & & & & & & & & & $\begin{array}{l}\text { Bleeding } \\
\text { events }\end{array}$ & $\begin{array}{l}\text { Thrombosis } \\
\text { event }\end{array}$ & Mol \\
\hline $\begin{array}{l}\text { Llitjos JF } \\
\text { et al }\end{array}$ & 22 & 2020 & France & $\begin{array}{l}\text { retrospective } \\
\text { cohort study }\end{array}$ & $\begin{array}{l}\text { March } 19 \\
\text { to April } 11 \\
2020\end{array}$ & 26 & $\begin{array}{l}68(51.5- \\
74.5)\end{array}$ & 77 & NA & NA & 18 & 3 \\
\hline $\begin{array}{l}\text { Hanif A et } \\
\text { al }\end{array}$ & 23 & 2020 & USA & $\begin{array}{l}\text { retrospective } \\
\text { series }\end{array}$ & $\begin{array}{l}\text { March } 15 \\
\text { to April } 14 \\
2020\end{array}$ & 921 & 62 (median) & 62.3 & 30.4 & 46 & NA & 543 \\
\hline $\begin{array}{l}\text { Nadkarni } \\
\text { et al }\end{array}$ & 16 & 2020 & USA & cohort sduty & $\begin{array}{l}\text { March } 1 \\
\text { to April } 30 \\
2020\end{array}$ & 4389 & $65(53-77)$ & 56 & $28(25-33)$ & 122 & NA & 149 \\
\hline $\begin{array}{l}\text { Pesavento } \\
\text { R et al }\end{array}$ & 24 & 2020 & Italy & $\begin{array}{l}\text { retrospective } \\
\text { study }\end{array}$ & $\begin{array}{l}\text { February } \\
26 \text { to April } \\
62020\end{array}$ & 324 & NA & 55.9 & NA & 17 & 8 & NA \\
\hline $\begin{array}{l}\text { Musoke N } \\
\text { et al }\end{array}$ & 25 & 2020 & USA & $\begin{array}{l}\text { single-center } \\
\text { retrospective } \\
\text { study }\end{array}$ & $\begin{array}{l}\text { March } 1 \\
\text { to May } 31 \\
2020\end{array}$ & 355 & $\begin{array}{l}66.21 \pm \\
14.21\end{array}$ & 51 & $29.71 \pm 9.11$ & 27 & NA & NA \\
\hline $\begin{array}{l}\text { Jimenez } \\
\text { Guiu X et } \\
\text { al }\end{array}$ & 26 & 2020 & Spain & $\begin{array}{l}\text { single-center } \\
\text { prospective } \\
\text { cohort study }\end{array}$ & $\begin{array}{l}\text { during } \\
\text { April } 2020\end{array}$ & 57 & $71.3 \pm 12.7$ & 50.9 & NA & 1 & 16 & NA \\
\hline $\begin{array}{l}\text { Paolisso P } \\
\text { et al }\end{array}$ & 27 & 2020 & USA & $\begin{array}{l}\text { retrospective } \\
\text { cohort study }\end{array}$ & $\begin{array}{l}\text { March } 1 \\
\text { to April } 10 \\
2020\end{array}$ & 450 & $67(55-79)$ & 63 & $26(24-30)$ & 4 & NA & 79 \\
\hline $\begin{array}{l}\text { Lemos } \\
\text { ACB et al }\end{array}$ & 28 & 2020 & Brazil & $\begin{array}{l}\text { randomised } \\
\text { open-label } \\
\text { phase } \otimes \text { study }\end{array}$ & $\begin{array}{l}\text { Not } \\
\text { mentioned }\end{array}$ & 20 & $56.5 \pm 13.08$ & 80 & $33.5 \pm 7.80$ & 6 & NA & NA \\
\hline $\begin{array}{l}\text { Andrew } \\
\text { Hsu et al }\end{array}$ & 29 & 2020 & USA & $\begin{array}{l}\text { restrospective } \\
\text { review }\end{array}$ & $\begin{array}{l}\text { February } \\
27 \text { to April } \\
242020\end{array}$ & 468 & NA & 54.9 & NA & 27 & 43 & 141 \\
\hline $\begin{array}{l}\text { Cho ES et } \\
\text { al }\end{array}$ & 30 & 2020 & USA & $\begin{array}{l}\text { single-center } \\
\text { retrospective } \\
\text { cohort study }\end{array}$ & $\begin{array}{l}\text { March } 1 \\
\text { to May } 13 \\
2020\end{array}$ & 158 & $67.4 \pm 14.6$ & 53.8 & $29.5 \pm 7.5$ & NA & 88 & NA \\
\hline $\begin{array}{l}\text { Benito N } \\
\text { et al }\end{array}$ & 31 & 2020 & Spain & $\begin{array}{l}\text { single-center } \\
\text { cohort study }\end{array}$ & $\begin{array}{l}\text { March 9 } \\
\text { to April } 15 \\
2020\end{array}$ & 76 & NA & 67.1 & NA & NA & 32 & NA \\
\hline $\begin{array}{l}\text { Zeng DX } \\
\text { et al }\end{array}$ & 32 & 2020 & China & $\begin{array}{l}\text { single center } \\
\text { retrospective } \\
\text { cohort study }\end{array}$ & $\begin{array}{l}\text { February } 9 \\
\text { to March } \\
92020\end{array}$ & 89 & $\begin{array}{l}72(63.5- \\
80.0)\end{array}$ & 62.9 & NA & NA & NA & 36 \\
\hline $\begin{array}{l}\text { Giacomelli } \\
\text { A et al }\end{array}$ & 33 & 2020 & Italy & $\begin{array}{l}\text { prospective } \\
\text { cohort study }\end{array}$ & $\begin{array}{l}\text { February } \\
21 \text { to April } \\
202020\end{array}$ & 233 & NA & 30.9 & NA & NA & NA & 48 \\
\hline $\begin{array}{l}\text { Secco E et } \\
\text { al }\end{array}$ & 34 & 2020 & Italy & $\begin{array}{l}\text { single-center } \\
\text { retrospective } \\
\text { case series }\end{array}$ & $\begin{array}{l}\text { March } 13 \\
\text { to April } 30 \\
2020\end{array}$ & 115 & $69(55-78)$ & 67.8 & NA & NA & NA & 18 \\
\hline
\end{tabular}

Of 14 included studies, 13 were retrospective studies, 1 was random clinical trials. The studies were major from 7 courtiers among which 6 ( $42.9 \%$ ) were from USA, 3 (21.4\%) were from Italy, followed by Spain(2), China(1), UK(1), Brazil(1) and France(1). The average/median age of the included study subjects was over 60 years old, and 13 articles were shown that male patients accounting for more than $50 \%$ of the participants. The sample size ranged from 26 to 4389 .

The comparison group in this study were separated based on their anticoagulation treatments: 1) the group with anticoagulant therapy vs. the group without anticoagulant therapy, and 2) the group received therapeutic vs. the group received preventive anticoagulant therapy.

\section{Bleeding Events}

There were 8 studies that had reported bleeding event rate for the Covid-19 patients receiving anticoagulation ${ }^{16,23-29}$.In general, there is no increasing trend of bleeding occurrence among those who received anticoagulation. The random efforts model shown that no significant difference between the cohorts with no anticoagulation and prophylactic anticoagulation (Fig. 2A). The same trend found in the comparison between no anticoagulation and anticoagulation (Fig. 2B). However, compared with cohort received prophylactic anticoagulation, the cohort with therapeutic anticoagulation had 2.17 times (95\% Cl: $1.45-$ 3.25) higher risk ratio of major bleeding rate, and 5.55 times higher risk ratio of other types of bleeding rate. Considering the general bleeding incidence rate, patients with therapeutic anticoagulation had 3.11 times $(95 \% \mathrm{Cl}: 2.29-4.24)$ higher bleeding rate than that of patients with prophylactic anticoagulation

(Fig. 2C).

\section{Thrombosis Events}


Thrombotic events among patients treated with anticoagulation were reported in 6 of the included studies ${ }^{22,24,26,29-31}$ and range of reported thrombosis events from 2.47-69.23\%. The percentage of deep venous thrombosis ranged from $6.62-55.70 \%$, and that of pulmonary embolism ranged from $2.56-$ $42.11 \%$. Specifically, Llitjos JF et al reported the overall rate of peripheral VTE as high as $69 \% 22$. Nevertheless, Andrew Hsu et al ${ }^{29}$, Cho ES et al ${ }^{30}$ and Benito $\mathrm{N}$ et $\mathrm{al}^{31}$ reported no significant difference in thrombosis events among the two comparision cohorts. Overall, the synthesis results indicates that the odds of developing deep venous thrombosis and pulmonary embolism was not statistically significant between the cohorts treated with no anticoagulation and prophylactic anticoagulation and was not statistically significant in the comparison between no anticoagulation and anticoagulation (Fig. 3A and 3B). Moreover, the odds of deep vein thrombosis in therapeutic anticoagulation was $66 \%$ (95\% Cl: $0.19-0.63$ ) lower than that of prophylactic anticoagulation, as showing in Fig. 3C.

\section{Mortality Event}

There were 6 studies that had reported mortality event rate for the Covid-19 patients receiving anticoagulation 22,24,26,29-31. There was basically only one paper for each subtype, and the death classification were combined based on the short course of Covid-19. The percentage of all morality event ranged from 11.54$58.96 \%$.For all type of mortality, including 28-day mortality, in-hospital mortality and all-cause mortality, cohorts treated with prophylactic anticoagulation were $20 \%$ (95\% Cl: 0.69-0.93) lower than that of cohorts treated with no anticoagulation, as showing in Fig. 4A. In comparison between cohorts treated with no anticoagulation and cohorts treated with anticoagulation, the trend was consistent as above (Fig. 4B). Furthermore, no statistically significant of general mortality rates between prophylactic anticoagulation and therapeutic anticoagulation (Fig. 4C).

Since substantial heterogeneity was not detected for bleeding, thrombosis or mortality rates, neitheramong anticoagulated cohort vs. the non-anticoagulated cohort,nor preventive anticoagulation cohort vs. therapeutic anticoagulation cohort (Fig. 2-4). We found no significant publication bias, as expected, based on the funnel plots (Supplementary Fig. 1-9).

\section{Discussion}

Our systematic review and meta-analysis of 14 studies involving 7,681 Covid-19 patients provides the a comprehensive examination of the risks of bleeding, thrombosis and death for patients with and without anticoagulation treatment, and patients underwent different types of anticoagulation treatment (prophylactic or therapeutic). The current results might indicates that prophylactic or therapeutic anticoagulation were superior to no anticoagulation in reducing the mortality.

Persistent evidence shown that pharmacological thromboprophylaxis can significantly reduce the risk of venous thrombus embolism for general patients ${ }^{35}$. However, the role of prophylactic anticoagulation in Covid-19 patients is unclear. Some studies revealed the potential benefits of anticoagulant treatment in severe Covid-19 patients with higher venous thrombus embolism risk ${ }^{36-38}$, such as reducing the mortality risk, while some studies indicated that routine chemical prophylaxis was inadequate in preventing venous thrombus embolism in severe Covid-19 patients ${ }^{39}$. In our study, anticoagulation treatment, no matter prophylactic or therapeutic, showed a mild effectiveness of reducing mortality among Covid-19 patients (Prophylactic anticoagulation vs No anticoagulation: $\mathrm{OR}=0.80,95 \% \mathrm{Cl}$ : 0.69-0.93; Anticoagulation vs No anticoagulation: $\mathrm{OR}=0.91,95 \% \mathrm{Cl}$ : 0.80-1.05). The results were consistent with current guidelines advocating treatment and the use of prophylactic and/or therapeutic anticoagulants in patients with Covid-19 appeared to be advocated 40 . According to the current studies, the mechanism of anticoagulant therapy could reduce the thrombosis in patients with Covid-19 might be as follows 41,42 . After SARS-CoV-2 causes infection, the virus would attack angiotensin converting enzyme 2 (ACE2) and decrease the ACE2 content, the role of ACE2 being to convert angiotensin II to angiotensin 1 and 7. Therefore, a decrease in ACE2 leaded to an increase in angiotensin II and a decrease in angiotensin 1 and 7 , and these changes in angiotensin levels leaded to an increase in superoxide levels. Recruitment of neutrophils leaded to an increase in superoxide production and an increase in superoxide production leads to endothelial cell dysfunction through the nitric oxide pathway. Because there were vesicles containing von Willebrand Factor (VWF) in endothelial cells, when a $500 \%$ increase in its activity, these vesicles exulted, and through a number of complex interactions, an increase in vWF could lead to an increase in local thrombus where the inflammation occurs.

Preventive and therapeutic anticoagulant therapy might have opposite clinical effectiveness of reducing bleeding and thrombosis for Covid-19 patients. Venous thromboembolic disease has been reported as one of the major complications occurring in patients with Covid-19 43 . Even in patients with Covid-19, there was currently no clear guidance on anticoagulant dose. Jimenez et al believed that patients could benefit from intermediate anticoagulation dosages ${ }^{26}$. Bleeding and thrombus were the two extremes of coagulation dysfunction ${ }^{44}$. Our results suggested that the risk of bleeding was greater with therapeutic anticoagulation than with prophylactic anticoagulation, while the risk of thrombus was greater with prophylactic anticoagulation than with therapeutic anticoagulation, which may be related to the treatment dose 45,46 . The results suggested the need to pay attention to drug dosage in anticoagulant therapy, and the need for higher level of evidence-based medicine. Therefore, the therapeutic dose should be carefully considered in clinical practice.

The literatures included in this study were not stratified according to severity of the disease, as a result, we could not evaluate the clinical benefits for mild and severe patients separately. But, when the severity of the disease was corrected as a confounding factor in a multivariate regression model, higher doses were found to be beneficial for the prevention of death, indicating that the effectiveness value was consistent across different disease degree stratification ${ }^{29}$. Another study showed a much higher frequency of pulmonary embolism in ICU patients with Covid-19 (21\%) than during the same time interval in 2019 (6\%), and it was also higher than the incidence of pulmonary embolism in patients with influenza admitted to the same ICU in 2019 (8\%) ${ }^{47}$. It seemed clear therefore that the incidence of pulmonary embolism in patients admitted to ICU with Covid-19 was much higher than in other critically ill non-Covid-19 patients, including those with acute respiratry distress syndrme and other respiratory infections, despite the fact that these patients are already at an increased risk of pulmonary embolism ${ }^{48}$. In the studies mentioned above ${ }^{39}$, as was the case in the present study, patients developed pulmonary embolism even though 
most of them were receiving anticoagulant thromboprophylaxis. These findings raise the need of that the dose of anticoagulant therapy should be carefully considered in the process of clinical diagnosis and treatment, particularly in higher risk Covid-19 patients ${ }^{6,49,50}$.

\section{Limitations}

Our study has several limitations. First, in the outcome event, subgroup analysis usually consisted of only one literature, for which we grouped each subtype into a single broad category, including bleeding events, thrombosis events, and death events. Second, this study was conducted when the disease outbreak is ongoing. Many regions affected by Covid-19 haven not yet published clinical datasets, which may skew the results of this analysis. All these datasets are retrospective, which prevents us from exploring risk factors. Additionally, due to the limitation of sample size, our analysis could not be divided into subgroups such as region and dose. Finally, the meta-analysis was performed by statistical result data, therefore there was no way to analyze case data according to more detailed clinical needs.

\section{Conclusion}

This review provides an anticoagulant therapy strategy for Covid-19 patients. Preventive anticoagulation could effectively reduce the risk of bleeding and pulmonary embolism and therapeutic anticoagulation could reduce the risk of deep venous embolism. Both treatment strategy had significant effectiveness in reducing the mortality risk. Our results would provide a reference for early anticoagulant therapy among patients with COVID-19.

\section{Abbreviations}

\section{COVID-19}

Coronavirus disease 2019

\section{SARS-CoV-2}

Severe acute respiratory syndrome coronavirus 2

VTE

venous thromboembolism

NOS

Newcastle-Ottawa Scale

ACE2

angiotensin converting enzyme 2

vWF

von Willebrand Factor

\section{Declarations}

\section{Ethical Approval and Consent to participate}

Not applicable.

\section{Consent for publication}

Not applicable.

\section{Availability of data and materials}

The datasets used and/or analyzed during the current study are available from the corresponding author on reasonable request.

\section{Competing interset}

The authors declare having no conflict of interest related to this work.

\section{Funding}

This review did not receive any specific grant from funding agencies in the public, commercial, or not-for-profit sectors.

\section{Authors' contributions}

Jingyi Ge, Zhipeng Wu and Yingmin Ma conceived the study and designed the protocol. Jingyi Ge and Zhipeng Wu conducted study selection and data extraction. Jingyi Ge, Zhipeng Wu and Yingmin Ma contributed to statistical analysis and interpretation of data. Jingyi Ge drafted the manuscript with all authors critically revising the manuscript.

\section{Acknowledgements}

Not applicable. 


\section{References}

1. WHO. Coronavirus Disease (COVID-19) Dashboard. 2021; https://covid19.who.int.

2. Zhou F, Yu T, Du R, et al. Clinical course and risk factors for mortality of adult inpatients with COVID-19 in Wuhan, China: a retrospective cohort study. Lancet. 2020;395(10229):1054-1062.

3. Tang N, Li D, Wang X, Sun Z. Abnormal coagulation parameters are associated with poor prognosis in patients with novel coronavirus pneumonia. $J$ Thromb Haemost. 2020;18(4):844-847.

4. Terpos E, Ntanasis-Stathopoulos I, Elalamy I, et al. Hematological findings and complications of COVID-19. Am J Hematol. 2020;95(7):834-847.

5. Connors JM, Levy JH. COVID-19 and its implications for thrombosis and anticoagulation. Blood. 2020;135(23):2033-2040.

6. Ranucci M, Ballotta A, Di Dedda U, et al. The procoagulant pattern of patients with COVID-19 acute respiratory distress syndrome. $J$ Thromb Haemost. 2020;18(7):1747-1751.

7. Bikdeli B, Madhavan MV, Jimenez D, et al. COVID-19 and Thrombotic or Thromboembolic Disease: Implications for Prevention, Antithrombotic Therapy, and Follow-Up: JACC State-of-the-Art Review. J Am Coll Cardiol. 2020;75(23):2950-2973.

8. Wise J. Covid-19 and thrombosis: what do we know about the risks and treatment? 2020(1756-1833 (Electronic)).

9. Zhang R, Ni L, Di X, et al. Systematic review and meta-analysis of the prevalence of venous thromboembolic events in novel coronavirus disease-2019 patients. Journal of vascular surgery. Venous and lymphatic disorders. 2021;9(2):289-298 e285.

10. Spyropoulos AC, Levy JH, Ageno W, et al. Scientific and Standardization Committee communication: Clinical guidance on the diagnosis, prevention, and treatment of venous thromboembolism in hospitalized patients with COVID-19. J Thromb Haemost. 2020;18(8):1859-1865.

11. Moores LK, Tritschler T, Brosnahan S, et al. Prevention, Diagnosis, and Treatment of VTE in Patients With Coronavirus Disease 2019: CHEST Guideline and Expert Panel Report. Chest. 2020;158(3):1143-1163.

12. Al-Samkari H, Karp Leaf RS, Dzik WH, et al. COVID-19 and coagulation: bleeding and thrombotic manifestations of SARS-CoV-2 infection. 2020(15280020 (Electronic)).

13. Kashi M, Jacquin A, Dakhil B, et al. Severe arterial thrombosis associated with Covid-19 infection. 2020(1879-2472 (Electronic)).

14. Carsana L, Sonzogni A, Nasr A, et al. Pulmonary post-mortem findings in a series of COVID-19 cases from northern Italy: a two-centre descriptive study. 2020(1474-4457 (Electronic)).

15. Ackermann M, Verleden SE, Kuehnel M, et al. Pulmonary Vascular Endothelialitis, Thrombosis, and Angiogenesis in Covid-19. 2020(1533-4406 (Electronic)).

16. Nadkarni GN, Lala A, Bagiella E, et al. Anticoagulation, Bleeding, Mortality, and Pathology in Hospitalized Patients With COVID-19. J Am Coll Cardiol. 2020;76(16):1815-1826.

17. Tang N, Bai H, Chen X, Gong J, Li D, Sun Z. Anticoagulant treatment is associated with decreased mortality in severe coronavirus disease 2019 patients with coagulopathy. 2020(1538-7836 (Electronic)).

18. Trigonis RA, Holt DB, Yuan R, et al. Incidence of Venous Thromboembolism in Critically III Coronavirus Disease 2019 Patients Receiving Prophylactic Anticoagulation. 2020(1530-0293 (Electronic)).

19. Stang A. Critical evaluation of the Newcastle-Ottawa scale for the assessment of the quality of nonrandomized studies in meta-analyses. 2010(15737284 (Electronic)).

20. Higgins JP, Altman Dg Fau - Gøtzsche PC, Gøtzsche Pc Fau - Jüni P, et al. The Cochrane Collaboration's tool for assessing risk of bias in randomised trials. 2011(1756-1833 (Electronic)).

21. Higgins JP, Thompson SG, Deeks JJ, Altman DG. Measuring inconsistency in meta-analyses. BMJ. 2003;327(7414):557-560.

22. Llitjos JF, Leclerc M, Chochois $C$, et al. High incidence of venous thromboembolic events in anticoagulated severe COVID-19 patients. $J$ Thromb Haemost. 2020;18(7):1743-1746.

23. Hanif A, Khan S, Mantri N, et al. Thrombotic complications and anticoagulation in COVID-19 pneumonia: a New York City hospital experience. Ann Hematol. 2020;99(10):2323-2328.

24. Pesavento R, Ceccato D, Pasquetto G, et al. The hazard of (sub) therapeutic doses of anticoagulants in non-critically ill patients with Covid-19: The Padua province experience. Journal of Thrombosis and Haemostasis. 2020;18(10):2629-2635.

25. Musoke N, Lo KB, Albano J, et al. Anticoagulation and bleeding risk in patients with COVID-19. Thromb Res. 2020;196:227-230.

26. Jimenez-Guiu X, Huici-Sánchez M, Romera-Villegas A, Izquierdo-Miranda A, Sancho-Cerro A, Vila-Coll R. Deep vein thrombosis in non-critically ill patients with coronavirus disease 2019 pneumonia: deep vein thrombosis in non-intensive care unit patients. Journal of vascular surgery. Venous and lymphatic disorders. 2020.

27. Paolisso P, Bergamaschi L, D'Angelo EC, et al. Preliminary Experience With Low Molecular Weight Heparin Strategy in COVID-19 Patients. Front Pharmacol. 2020;11:1124.

28. Lemos ACB, do Espirito Santo DA, Salvetti MC, et al. Therapeutic versus prophylactic anticoagulation for severe COVID-19: A randomized phase II clinical trial (HESACOVID). Thromb Res. 2020;196:359-366.

29. Hsu A, Liu Y, Zayac AS, Olszewski AJ, Reagan JL. Intensity of anticoagulation and survival in patients hospitalized with COVID-19 pneumonia. Thromb Res. 2020;196:375-378. 
30. Cho ES, McClelland PH, Cheng O, et al. Utility of d-dimer for diagnosis of deep vein thrombosis in coronavirus disease-19 infection. Journal of vascular surgery. Venous and lymphatic disorders. 2021;9(1):47-53.

31. Benito N, Filella D, Mateo J, et al. Pulmonary Thrombosis or Embolism in a Large Cohort of Hospitalized Patients With Covid-19. Front Med (Lausanne). 2020;7:557.

32. Zeng D X , Xu J L, Mao Q X, et al. Association of Padua prediction score with in-hospital prognosis in CoVID-19 patients[J]. QJM: An International Journal of Medicine, 2020.

33. Giacomelli A, Ridolfo AL, Milazzo L, et al. 30-day mortality in patients hospitalized with COVID-19 during the first wave of the Italian epidemic: a prospective cohort study. Pharmacological research. 2020;158:104931.

34. Secco E, Pasqualetto MC, Bombardini T, Picano E, Rigo F. A possible benefit from therapeutic anticoagulation in patients with coronavirus disease 2019: the Dolo hospital experience in Veneto, Italy. Kardiol Pol. 2020;78(9):919-921.

35. Stuck AK, Spirk D, Schaudt J, Kucher N. Risk assessment models for venous thromboembolism in acutely ill medical patients. A systematic review. Thromb Haemost. 2017;117(4):801-808.

36. Kollias A, Kyriakoulis KG, Dimakakos E, Poulakou G, Stergiou GS, Syrigos K. Thromboembolic risk and anticoagulant therapy in COVID-19 patients: emerging evidence and call for action. Br J Haematol. 2020;189(5):846-847.

37. Tang N, Bai H, Chen X, Gong J, Li D, Sun Z. Anticoagulant treatment is associated with decreased mortality in severe coronavirus disease 2019 patients with coagulopathy. J Thromb Haemost. 2020;18(5):1094-1099.

38. Escher R, Breakey N, Lammle B. Severe COVID-19 infection associated with endothelial activation. Thromb Res. 2020;190:62.

39. Maatman TK, Jalali F, Feizpour C, Douglas A. Routine venous thromboembolism prophylaxis may be inadequate in the hypercoagulable state of severe coronavirus disease 2019. Critical care medicine. 2020.

40. Thachil J, Tang N, Gando SA-O, et al. ISTH interim guidance on recognition and management of coagulopathy in COVID-19. (1538-7836 (Electronic)).

41. Kai H, Kai M. Interactions of coronaviruses with ACE2, angiotensin II, and RAS inhibitors-lessons from available evidence and insights into COVID-19. 2020(1348-4214 (Electronic)).

42. Singh SA-O, Pritam M, Pandey B, Yadav TP. Microstructure, pathophysiology, and potential therapeutics of COVID-19: A comprehensive review. 2020(10969071 (Electronic)).

43. Chen J, Wang X, Zhang S, et al. Findings of Acute Pulmonary Embolism in COVID-19 Patients. Lancet Infect Dis Thromb Res. 2020;190:58-59.

44. Connors JM, Levy JH. COVID-19 and its implications for thrombosis and anticoagulation. 2020(1528-0020 (Electronic)).

45. Dobesh PA-O, Trujillo TC. Coagulopathy, Venous Thromboembolism, and Anticoagulation in Patients with COVID-19. 2020(1875-9114 (Electronic)).

46. Kollias AA-O, Kyriakoulis KG, Dimakakos E, Poulakou G, Stergiou GS, Syrigos K. Thromboembolic risk and anticoagulant therapy in COVID-19 patients: emerging evidence and call for action. 2020(1365-2141 (Electronic)).

47. Poissy J, Goutay J, Caplan M, et al. Pulmonary Embolism in Patients With COVID-19: Awareness of an Increased Prevalence. Circulation. 2020;142(2):184-186.

48. Spyropoulos AC, Ageno W, Barnathan ES. Hospital-based use of thromboprophylaxis in patients with COVID-19. Lancet. 2020;395(10234).

49. Klok FA, Kruip M, van der Meer NJM, et al. Incidence of thrombotic complications in critically ill ICU patients with COVID-19. Thromb Res. 2020;191:145147.

50. Helms J, Tacquard C, Severac F, et al. High risk of thrombosis in patients with severe SARS-CoV-2 infection: a multicenter prospective cohort study. Intensive Care Med. 2020;46(6):1089-1098.

\section{Figures}




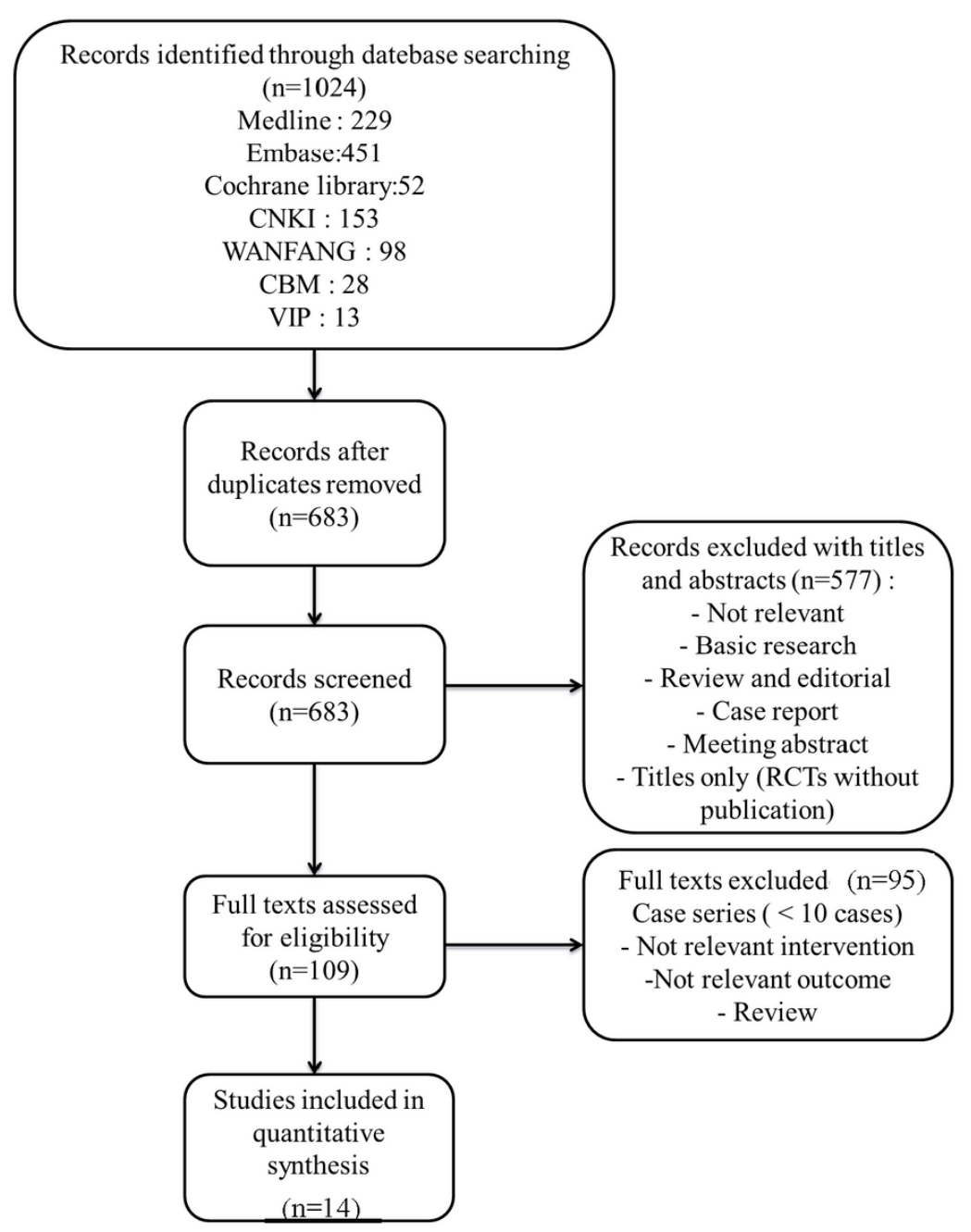

\section{Figure 1}

Flow diagram of publication selection 

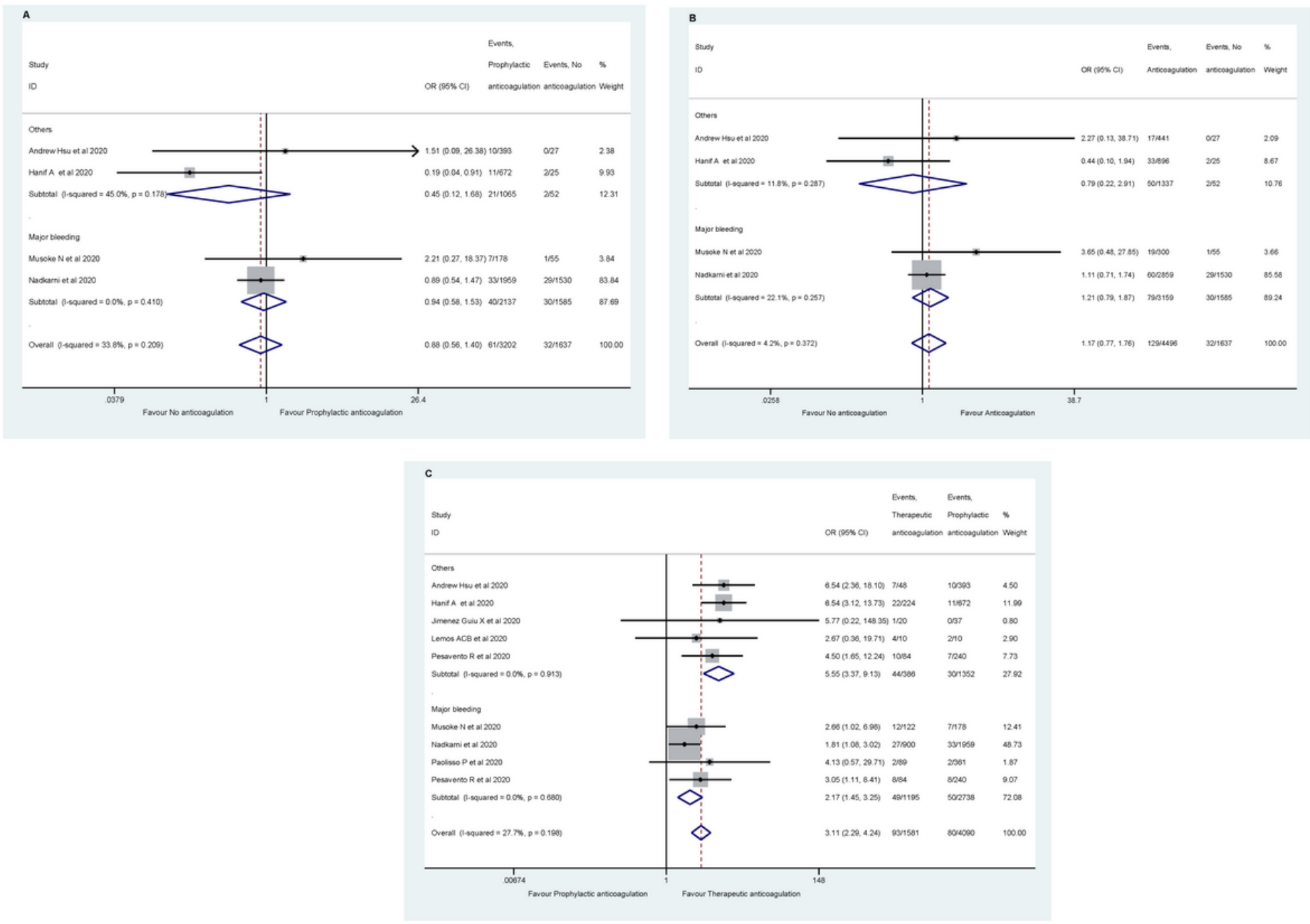

\section{Figure 2}

Meta-analysis of the bleeding risk comparison (A for Prophylactic anticoagulated vs No anticoagulated; B for Anticoagulated vs No anticoagulated; C for Prophylactic anticoagulated vs Therapeutic anticoagulated)
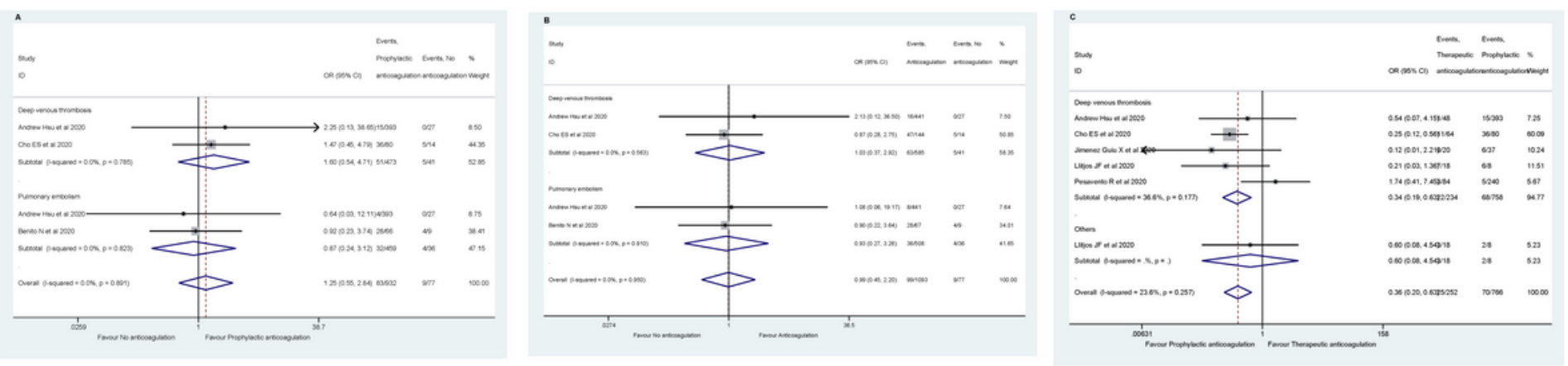

Figure 3

Meta-analysis of the thrombosis risk comparison (A for Prophylactic anticoagulated vs No anticoagulated; B for Anticoagulated vs No anticoagulated; C for Prophylactic anticoagulated vs Therapeutic anticoagulated) 

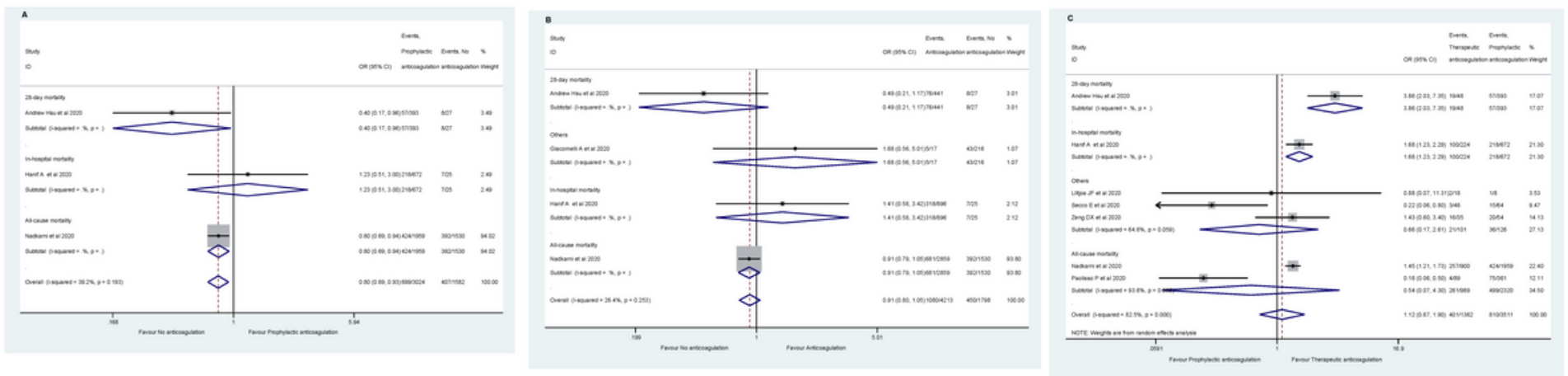

\section{Figure 4}

Meta-analysis of the death risk comparison (A for Prophylactic anticoagulated vs No anticoagulated; B for Anticoagulated vs No anticoagulated; C for Prophylactic anticoagulated vs Therapeutic anticoagulated)

\section{Supplementary Files}

This is a list of supplementary files associated with this preprint. Click to download.

- Supplementaryfigure1.pdf

- Supplementaryfigure2.pdf

- Supplementaryfigure3.pdf

- Supplementaryfigure4.pdf

- Supplementaryfigure5.pdf

- Supplementaryfigure6.pdf

- Supplementaryfigure7.pdf

- Supplementaryfigure8.pdf

- Supplementaryfigure9.pdf

- supplementarycontent20210428.docx 